\title{
Child Protection System and Challenges in Pakistan
}

Dr Venkat Pulla, ${ }^{+*}$ Maliha Gul Tarar ${ }^{\prime}$ and Amber Ali

\section{Abstract}

Child protection refers to preventing and responding to child abuse and exploitation, that is, child labour, trafficking, commercial sexual exploitation, and harmful customary practices. This paper is about child protection issues in Pakistan, one of the South Asian countries in the Indian subcontinent. Pakistan has agreed to provide children with special protection, as a signatory to the United Nations Convention on the Rights of the child [UNCRC]. Consequently, it is mandatory for the state to protect children. The authors review both internal and external factors affecting child protection in Pakistan in addition to outlining the challenges faced by South Asian countries in the realm of child protection. It then draws recommendations for efficient child protection system in Pakistan.

Keywords: Violence, Child Rights, State, Social Welfare, Child Protection, Pakistan

\footnotetext{
${ }^{\dagger}$ Senior Lecturer, Australian Catholic University, Brisbane and Adjunct Senior Research Fellow at the Institute for Land, Water and Society, Charles Sturt University, Australia, Emails: Venkat.pulla@acu.edu.au; vpulla@csu.edu.au ${ }^{*}$ Corresponding Author

'Lecturer in Social Work, University of Sargodha, Sargodha, Pakistan, Email: malihatarar@yahoo.com

I MSW, (ACU) is an Intensive Family Support Practitioner working in Australia, Email: aqa_amber@hotmail.com (C) 2018 Pulla et al. This is an Open Access article distributed under the terms of the Creative Commons Attribution License (http://creativecommons.org/licenses/by/2.0), which permits unrestricted use, distribution, and reproduction in any medium, provided the original work is properly cited.
} 


\section{Introduction}

In South Asia, children are expected to be submissive to their elders and to tolerate violence. Rather than mutual trust and affection, they often have a complianceobedience relationship with their adults. Psychological as well as physical abuse has been found to be the primary motive for children of South Asia (including Pakistan) quitting school, leaving homes or ending up on the street, in jails or sex trades (Save the Children, 2010; Heiberg, 2005; see also, Bhattacharyya, 2017; 2018). A Save the Children \& UNICEF study (2005) reported that violence against children is an accepted and inevitable part of South Asian societies, and due to stigma, shame and guilt, it is highly underreported (Masood et al. 2012; Mehnaz, 2011; Solotaroff and Pande, 2014). Findings of another study entitled South Asia Initiative to End Violence Against Children, 2011 conducted in Khyber Pakhtunkhwa, Pakistan with 500 teachers, 1200 parents and 3,500 children aged 6-14 revealed that all children faced some form of common punishments in schools and homes such as ear-pulling, ear-twisting, hair-pulling, punching, kicking, smacking, humiliating in addition to awkward physical positions, and hitting with a stick, knife, rod, brick, or shoe. Thus, vulnerability of children is witnessed on many fronts - such as home and family, schools and educational settings, care and justice system, and child labour in work settings. Due to this, child protection is a recent entry into the South Asian nations ${ }^{1}$ agenda (Pulla, 2014). In a previous review of the South Asian countrywide initiatives about a development of child protection systems and cross-border collaboration between the above countries, a need to reinforce multistakeholder partnerships in child protection system in these nations was suggested (Pulla, 2014). In this paper, we focus on the challenges faced by the state-run child protection agencies in Pakistan. In doing so, the authors examine

\footnotetext{
${ }^{1}$ The SAARC nations are Pakistan, Bangladesh, Nepal, Sri Lanka, Maldives, Afghanistan, and Bhutan
}

the internal and external factors affecting child protection in Pakistan.

Pakistan is a federation made up of provinces and territories. Pakistan's child protection system is influenced by the traditional values held by the different cultures and values that prevail in the provinces, and so legislation varies throughout the country. This disjointed approach highlights the struggle the Pakistan government has in balancing international obligations and societal values regarding child protection (Jabeen, 2016). Despite being a signatory to the United Nations Convention on the Rights of the Child [UNCRC] and related protocols and conventions, Pakistan is the fifth amongst the countries that has a very bleak picture for its children as they continue to be subjected to violence, lawlessness and denial of fundamental rights (Mehnaz, 2011). The role of Pakistan's child protection system is to prevent and address discrimination, neglect, exploitation, and abuse affecting children but there are many barriers to achieving adequate outcomes in this regard. By definition, child protection involves structures and measures designed to prevent and respond to neglect and abuse. It is the process of protecting individual children identified either as suffering or likely to suffer considerable harm due to abuse or neglect (Royal College of Pediatric and Child Health, 2016). According to the Child Protection System Mapping and Assessment report, commissioned by the UNICEF, that covers all provinces of Pakistan: "[a] child protection system constitutes of structures, functions, and capacities that work together for child protection goals. It works on several levels of society, from the government to community, and engages several actors, including government and civil society organizations or representatives" (Khan et al., 2013: p.1). Undoubtedly, Pakistan's child protection system is structured around the themes related to children and justice, preventing commercial and sexual exploitation, protecting children without adequate family care through alternative care, provision of protection in emergencies and (or) in armed conflict. There is however, very little research 
on the child protection issues in Pakistan on psychological and physical neglect and abuse, child labour, birth registration and harmful cultural practices (Khan et al., 2013).

Pakistan's family system can be seen on a continuum. There are still some remnants of the joint family system, which is supposed to an influence of Hindu family. Indeed, a traditional joint family system fall along has been construed as a provider of a safety net, that took care of the needs of children. Children were rarely abandoned unless forced by social circumstances such as being born out of wedlock. The problem is that poverty, illiteracy, lack of awareness and the power of the offenders can compromise this system. The traditional conservative and patriarchal system of Pakistan's tribal society can be a barrier to adequate child protection by its attempt to protect the guilty (Jabeen, 2016). The government and voluntary philanthropic organisations have also taken responsibility for the care of vulnerable groups of children (Rehmatullah, 2002). However, Human Rights Commission of Pakistan reported in 2014 that Pakistani children are susceptible to exploitation, abuse, violence due to severe weakness in the legal and social protection framework (Jibeen and William, 2014).

The need for a consistent and well-defined system of child protection for Pakistan is imperative when you consider the environmental disasters and wars that are affecting the country. For example, about 4 million children were displaced because of the military operation in tribal areas, and a considerable number was affected by floods in the Punjab, Kashmir, and Sindh. Moreover, in 2014, 650 children died in drought-affected areas of Sindh. Because of a brutal massacre in the Army Public School in Peshawar, 132 students were killed, but the state failed in giving child rights a priority (Jabeen, 2016). In such situations, it is imperative to explore about prevailing child protection system in Pakistan for policy and administrative reforms. The following two sections discuss the internal and external factors affecting child protection in Pakistan. It then examines the existing child protection system of Pakistan and the challenges therein. Finally, it makes recommendations for efficient child protection system in Pakistan.

\section{Internal Factors}

The future of any nation is dependent upon the experiences of the children that grow up in its society (Hobbs et al., 1993). In developing countries such as Pakistan, poverty is one of the barriers to efficiently protecting children's rights. Poverty affects an individual's and communities' ability to cope with adversity. People in poverty are at risk of remaining vulnerable as assistance is beyond poorly resourced support systems (Jabeen, 2016). In Pakistan, a child might be fortunate to be a part of the upper strata of the society. Most commonly known as the upper and uppermiddle-class families, ${ }^{2}$ possibly with the rights that ensure healthy food, sleep in a secure house, get a decent education, and have adequate clothes to fight against the harsh climates and to be free from exploitations (Malekpour, 2004).

Pakistan's class has its roots in centuries of the old heritage left by various dynasties such as the Mughal Empire and the British rulers. Even in today's dynamic world, the power of caste and creed holds deep standing in Pakistani society (Gazdar, 2004; Suhail, 1990). If we dissect this concept of child protection system, it projects light on the influential families that hire young children to work on their agricultural lands, in their homes and offices. This observation bears resonance to previous reports published by the International Labour Organization (ILO) (Khan and Lyon, 2015). In addition, this observation also validates Nobel Laureate Kailash Satyarthi's Bachpan Bachao Andolan (BBA) and Global March against Child Labour (please refer to also, Bhattacharyya, 2015; 2017; 2018).

\footnotetext{
${ }^{2}$ It is believed that over 25 per cent of families and over 50 per cent of urban families constitute the middle class in Pakistan as per the report of Durr-e-Nayab, Pakistan Institute of Development Economics, Islamabad, 2011.
} 


\section{Child Labour in the age group 5- 14 Numbers}

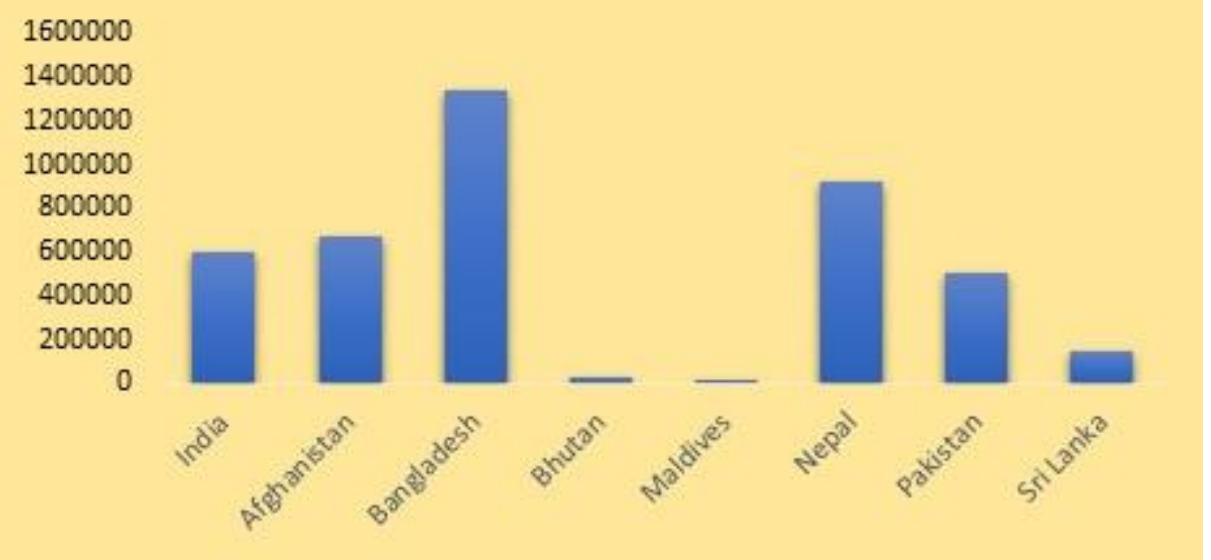

Figure 1: Child Labour in South Asia

Source: While the Data on Afghanistan is sourced from Constructed from Report: Afghanistan, Moderate Advancement Report, (p.10), US Dept. of labour's Bureau of International Labour Affairs, Dolgov. (2018). Dolgov. Retrieved 3 March 2018, from https://www.dol.gov/ilab/reports/child-labor/findings/2014TDA/afghanistan.pdf The rest of the data has been sourced from, Khan, Sherin and Lyon Scott (2015). Measuring Children's Work in South Asia: Perspectives from national household surveys, International Labour Organization, retrieved on 22 February 2018 from, http://www.ilo.org/wcmsp5/groups/public/--asia/---ro-bangkok/---sro-new_delhi/documents/publication/wcms_359371.pdf.

According to the ILO, in South Asia, 16.7 million (5-17-year-old) children are engaged in some form of child labour (Khan and Lyon, 2015). Of these, children within the age-group of 5-11 constitute one-fifth of the total child labour in South Asia (Khan and Lyon, 2015). The ILO report mentions that child labour represents about 5.8 million in India, 5.0 million in Bangladesh, 3.4 million in Pakistan and close to 2.0 million in Nepal. In India, as per the latest statistics available at BBA website, ${ }^{3}$ since 1980 BBA has rescued 86516 children from the clutches of slavery and bonded labour (see also, Bhattacharyya, 2017; 2018). Figure 1 paints a detailed picture of child labour in South Asia.

Poverty is a critical issue in the Pakistani economics. Poverty in Pakistan has historically been higher in rural than urban areas. A multidimensional poverty study carried out by Masood et al., (2012) pointed out that poverty households were found to be lacking in five

\footnotetext{
${ }^{3}$ Bachpan Bachao Andolan, retrieved on 22 February 2018 from, https://www.bba.org.in/
}

dimensions: empowerment, land, housing, sanitation and asset. Overall, 22.8 per cent households of Pakistan live below the expenditure poverty line, and in urban areas, 11.3 per cent are expenditure deprived while in rural areas, 28.6 per cent are expenditure deprived.

According to another survey conducted by Sustainable Development Policy Institute (SDPI), in Pakistan, 58.7 million people live in multidimensional poverty ${ }^{4}$ and 21 per cent of the households are abysmal poor (Naveed, \& Ali, 2012; Samra, 2014). The survey measured poverty using five primary indicators - water supply and sanitation, health, education, satisfaction with service delivery and household assets/amenities. The children and the adults living in the households of multidimensional poverty do not have access to clean water, two

\footnotetext{
${ }^{4}$ Further clarity on the multidimensional poverty can be obtained from thttp://ophi.org.uk/multidimensionalpoverty-index/ and the data for Pakistan's MPI is available at

http://www.dataforall.org/dashboard/ophi/index.php/m pi/country_briefings
} 
meals a day, a safe place to sleep (Naveed, \& Ali, 2012; Samra, 2014). Education comes further down in the priorities of the poor. Children in families experiencing poverty are called upon to work for their basic life needs of the families they belong to including taking care of their younger siblings. Child labour as domestic help, working in the measly paid restaurant or providing assistance at tea stalls, car and scooter mechanic shops or as a street vendor is not uncommon. If none of the above alternatives is unavailable, they end up on the streets to beg. These children in the above settings are often ill-treated and emotionally and physically abused. They are frequently found underfed, malnourished, dressed in rags and sometimes disease ridden due to the unhygienic conditions that they live in.

After India and China, Pakistan has been ranked third in the "Global Slavery Index 2016" with 2.13 million slaves, the majority of them working in agriculture and brick making (The Walk Free Foundation, 2016). In a similar context, Hopkins (2014) reported that more than 2 million people in Pakistan are trapped in modern-day slavery. The International Labour Organization (ILO, 2011) estimated that millions of Pakistani children under the age of fourteen are involved in exploitative, hazardous, and physically demanding labour that includes domestic service, crop agriculture, street and service industries, mining and quarrying, brick kilns and rag picking (Khan and Lyon, 2015). They are often not able to attend schools and enjoy time with peers because their physical exercise as child labour already takes their mind and body. Evidently, the families of these children are usually in debt of the wealthy landlords (or property owners). Hence, they give away their child for a predecided number of years and the services rendered by these children are then used as a means to pay-off the debt. The ages of these children could be as young as 3-4 years (Arif, 2004; Labour Watch Pakistan, 2011; Osment, 2014; Bureau of International Labour Affairs, 2015). However, the pre-decided tenure of service for these children keeps changing as the family gets itself tangled in the never-ending series of debts. There have been cases where the family had to surrender their girl-child to the elderly yet powerful landlord in marriage (Arif, 2004; Labour Watch Pakistan, 2011; Osment, 2014; Bureau of International Labour Affairs, 2015). Moreover, because of the high prevalence of child labour, it is impossible for Pakistan to achieve Millennium Development Goals (MDGs) relating to education, gender equality, HIV/AIDS and poverty reduction. The following Figure 2 illustrates the position of child labour in Pakistan. ${ }^{5}$

\section{External Factors}

Pakistan is blessed to be located in the most significant geographical position, globally; however, this comes at a high price. The changing geopolitical environments affect the common person directly. This can be regarding inflation, severity in budget cuts, and even war. Even at this point, Pakistan is in an active war situation in its Western and Northwestern border cities. The assimilation of the terrorist organisation such as Al-Qaida and Taliban in Pakistan's Northwestern province has encapsulated the entire country in a wave of severe terrorism. Consequently, every year, thousands of children are left as orphans and no families to go to. These children then face the fate in shape of kidnappings, recruitments by the same terrorist organisations or left on the streets to pick up their life from there in whatever way possible. This observation echoes a similar finding as reported by Bhattacharyya (2017) in her research on India's missing children (see also, Bhattacharyya, 2018).

More than in any other country, during 20092012, 838 or more schools were attacked in Pakistan. Parallel to Pakistan Government's educational system, madrassas offer free

\footnotetext{
${ }^{5}$ Measuring Children's Work in South Asia: Perspectives from national household surveys, International Labour Organization, retrieved on 22 February 2018 from, http://www.ilo.org/wcmsp5/groups/public/---asia/---robangkok/---sronew_delhi/documents/publication/wcms_359371.pdf.
} 


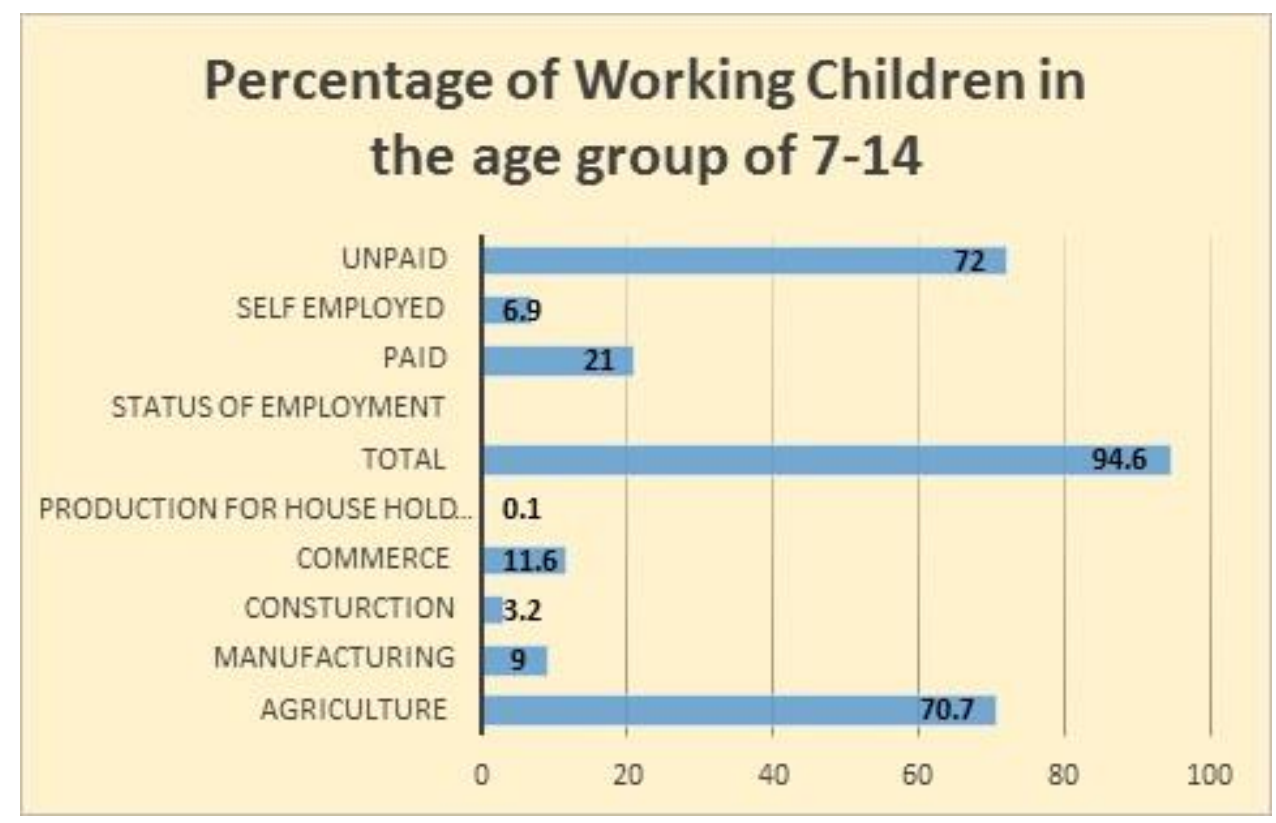

Figure 2

Source: Khan, Sherin and Lyon Scott (2015). Measuring Children's Work in South Asia: Perspectives from national household surveys, International Labour Organization, retrieved on 22 February 2018 from, http://www.ilo.org/wcmsp5/groups/public/---asia/---ro-bangkok/---sronew_delhi/documents/publication/wcms_359371.pdf.

Islamic education, boarding and lodging for schools and madrassas (Global Coalition to poor students hailing from remote areas. There are approximately 12,000 registered madrasas in Pakistan. These madrassas have their own syllabus and examination as they work under Wafaq-ul Madaras Al Arabia of Pakistan. However, there are many unregulated and unregistered madrasas. An action is needed to regulate and monitor those unregistered madrasas as they are highly speculated to operate as recruiting agencies of Taliban (Tohid, 2011). To further reinforce this, it is believed that the militant groups recruit poor children from the madrassas and schools (Tohid, 2011). Unfortunately, some of them were used as suicide bombers (Global Coalition to Protect Education from Attack, 2014). Azami (2014) reported that the number of child suicide bombers is increasing due to the disturbing regional twist. The poor parents and guardians remain unaware that their children are recruited merely for being children. Moreover, some detained children disclosed in interviews that they were abducted from lowincome neighbourhoods and streets. There is also evidence to suggest that militant groups kidnap children on their en route to and from Protect Education from Attack, 2014). Pakistani military officials said that different Taliban groups used to sell children for $\$ 6,000$ to $\$ 12,000$. A video was also released by Pakistan army showing children training for their attacks (Kassim, 2011).

Natural calamities also form an integral part of the journey of thousands of children. Pakistan is involved in an ongoing conflict with its neighbouring country over Kashmir. Apart from this, Pakistan is also engaged in conflict over water channels and their flow as flooding is an annual occurrence in Pakistan especially in the provinces of Punjab and Khyber Pakhtunkhwa. Every year, thousands of families are left stranded consequently leaving the same cycle for children to step out and assist their families as discussed above. The most severe flood in Pakistan's history affected at least 18 million people in 2010. Consequently, approximately 3.5 million children were at risk of disease (Azami, 2014; BBC, 2010; 2011).

Two major and several minor earthquakes have hit Pakistan in the past decade. The first major earthquake in 2005 followed by a more recent 
one in 2015 has resulted in scores of children becoming homeless, losing families, being kidnapped and facing an unfortunate fate. Only a minority of these children were fortunate enough to find homes and become a part of a loving family (UNICEF, 2015; Human Appeal, 2016).

\section{Existing Child Protection System in Pakistan and the Challenges}

Child protection is an aspect of a social value system that has been emphasised upon every religion of the world. Pakistani society is predominantly Muslim, hence, follows the rulings of Islam. The rights of every child are under complete protection by a wide-ranging set of social and religious as well as legal standards. These play the role of instruments that ensure that the child is protected, benefitted, looked after, and provided for. As a religion, Islam also gives clear instructions in forms of legal rights and several provisions to provide an extra layer of protection to children, which then enable them to maintain healthy growth and developmental pattern.

Before the partition of the subcontinent in 1947, laws to protect children against all exploitations already existed and the then government under the British had established correctional and educational institutes for juvenile offenders and the disabled. In addition, voluntary organisations established orphanages and educational institutes for children. Hence, at the time of partition, Pakistan inherited a legacy of child welfare devoted primarily to remedial services. The new government assigned the responsibility of the rehabilitation of the visually and hearing handicapped to the Education Department, and the Ministry of Interior handled the juvenile delinquency as a law enforcement agency (Rehmatullah, 2002).

The international community requires a criteria and framework for the protection of children worldwide and the World Summit for Children as well as the UN Convention on the Rights of the Child have been able to set out some minimum standards for children's education, health, survival and minimum protection required by the children against neglect, exploitation and abuse in the home, at work or in war (Munir, 1993). To meet international and national standards such as the UN Convention on the Rights of the Child, it is challenging and vital that all the countries develop a systematic approach to child protection. A systematic approach to child protection demands the coordination, commitment, and attention of the governments and other segments of the society, that is, families, academia, the private sector, children, caregivers, and the NGOs. Child protection requires a national strategy, targeted policies and programming, trained officials, multi-disciplinary and multi-sectoral cooperation, child-friendly judicial system, sound legal framework, comprehensive referral system including reporting, care and rehabilitation services, identification of child victims of violence as well as public awareness and research to prevent violence (Save the Children, 2010).

As a signatory to the Convention on the Elimination of All Forms of Discrimination Against Women (CEDAW), the United Nations Convention on the Rights of the Child (CRC) and other Protocols and Conventions, it is obligatory for Pakistan to protect children from hazardous labour, prostitution, sale and discrimination on the basis of disability or education. Pakistan's child protection system consists of both formal and informal institutions and actors. However, after the 18th constitutional amendment in 2010, the devolution process has changed the policy, political, programmatic and service context of child protection, and now the provinces have sole responsibility to legislate and administrate on all child protection relevant issues (Khan et al., 2013).

The Human Rights Commission of Pakistan (2014) reported that the Pakistan government has not been able to make significant improvement or addition in the protection framework for children. However, the announcement of the set-up of a National Commission for Children by the Office of National Commissioner for Children Wafaqi Mohtasib (Ombudsman's) Secretariat is the 
only remarkable step taken in this regard. Pakistan has been identified as the first country in South Asia to establish a specific Ombudsman's office for children, with a Children's Complaints Office housed since 2009 in the Secretariat of the Wafaqi Mohtasib (Ombudsman) of Pakistan. Established with the UNICEF support, the Children's Complaints Office serves as a dedicated mechanism where complaints from and with regard to children can be received and processed. These can include allegations of maladministration in public institutions such as concerned Ministries. Critically, this initiative bridges an existing gap regarding child-specific grievances and provides a redress mechanism. In due course, this service is to be expanded to cover all eight sub-national offices of the Wafaqi Mohtasib. Complaints can be filed online and by email. In the Punjab province, Child Protection Courts also have been established in seven district-level Child Protection and Welfare Bureaus since 2004 (UNICEF, 2014).

The Punjab Social Welfare Department has been in the process of drafting a child protection policy since 2011 in collaboration with UNICEF. Civil society organisations have a consortium known as the Child Rights Movement (CRM), which is working to promote the cause of children. The CRM urged the state to introduce child protection policy and drew a petition to gain support for the enactment of pending child protection bills (Human Rights Commission Pakistan, 2014).

The Government of Punjab established Child Protection and Welfare Bureau in March 2004 to provide rehabilitation, care, training, and education to the neglected and destitute children. The Bureau is working for the reunification of children with their families as well as to protect these children from criminals with the help of a dedicated team of highly motivated professionals and educated officers, which includes psychologists, doctors, child protection officers, and law officers. The Bureau has established Child Protection Institutions in Rawalpindi, Sialkot, Multan, Bahawalpur, Gujranwala, and Faisalabad where neglected and destitute children can get food, education, shelter and skills to be a useful citizen. To address the issues like legal reunification and custody of the children with their parents, a child protection court has also been established. Moreover, a child helpline has also been set up to provide help, coordination, and guidance for their protective and rescue custody (Government of the Punjab, 2016). The Child Protection and Welfare Bureau is delivering its services with coordination of Social Welfare Department, Police Department, UNICEF, Health Department, Law Department, Pakistan Railways, Education Department, City Traffic Police, Public Prosecution Department, Punjab Information Technology Board, City District Government and Federal Investigation Agency (Government of the Punjab, 2016).

In order to have a reduced level of global violence, the world needs to fight violence against children in South Asia collectively (UNICEF, 2013). According to the statistical data, South Asia is home to an average of 64.5 million children who witness violence at home. Unfortunately, this is the highest regional total in the world. At the same time, around 44 million children have been reported as active child labourers, and almost half of the world's child brides live in South Asia (UNICEF, 2014) as detailed in their report titled 'ending child marriages: progress and prospects. The figures given above are general indicators of the situation that the children in this region continue to face.

Pakistan is an integral part of the South Asian Association for Regional Cooperation (SAARC). In the SAARC charter of child rights, the health development and well-being of children in SAARC countries have been ranked as the top priority. Since its inception more than three decades ago, SAARC has been continuously making efforts towards the strengthening of child protection system in Pakistan. In 2001, SAARC declared the SAARC Decade of the Rights of the Child 2001-2010 (UNICEF, 2014). In Pakistan, the National Commission for Child Welfare and Development (NCCWD) operates by the charter of child rights as determined by 
SAARC (NCCWD, 1980). However, the children of Pakistan are still waiting for the time when the political forces and peak bodies and stakeholders will come together on a platform, and the NCCWD will be implemented in its full form.

The 2013 Asia-pacific Roundtable Meeting on Violence (UNESCO, 2014) states that:

All forms of violence (explicit and symbolic forms of violence), including fear of violence, that occurs in education contexts (including nonformal and formal contexts such as school premises, on the journey to and from school, and in emergency and conflict settings) which result in, or are likely to result in, physical, sexual or psychological harm of children (female, male, intersex and transgender children and youth of all sexual orientations) is based on stereotypes, roles or norms, attributed to or expected of children because of their sex or gender identities. Marginalisation and other vulnerabilities can compound it.

The worst kinds of child abuse are child sexual abuse, child labour, child trafficking, commercial exploitation of the child, early child marriages and involvement of children in drugs and drug trafficking (Right Vision News, 2013). The cultural, religious and social value system of Pakistan goes hand in hand with the concept of no tolerance for such misdeeds mentioned above. However, in reality, it is not entirely accurate. Child sexual and physical abuse is present in many forms in society at the hands of family, friends, teachers, religious clerics, employers, members of the law enforcing agencies, etc. At the same time, it is a taboo, so no one speaks about it, and the truth is kept under wraps to save the good name of the child or his or her family. The offenders are people of influence, whether socially, financially or religiously. The detrimental effects of such behaviours damage the emotional and sometimes physical health of these children (Parton, 2011).
According to the Constitution of Pakistan (Government of Pakistan, 1973), it is the fundamental right of every citizen to access health facilities and services, but the reality of implementing these rights is not possible as the budgetary allocations for social welfare, education and health are meagre. In the federal budget for child-focused social welfare schemes and programs seems to be declining over the years (Khoso et al., 2012). Figure 3 shows budget declines. Although the current data is unavailable, Figure 3 further illustrates the deterioration of budgetary allocation in a 4year period as per the Institute for Social Justice Report (Isjorgpk, 2018). The overall budgetary situation is less conducive to the welfare of the children.

Pakistan homes one of the most significant military forces in the world. This then leads to a tightening of funding to other sectors such as education, health and other departments that could be working for the welfare and security of children in Pakistan. The average share of children in government budgets is around 6 per cent (Figure 4), but children form more than 48 per cent of Pakistan's population (Isjorgpk, 2018).

Despite the existing legislation for the child protection system, the cycle of a failing child protection system is related to lack of resources. Child protection experts have globally determined that children need protection from physical harm, exploitation and gender-based violence, psychosocial distress, recruitment into armed groups, family separation, abuses related to forced displacement and denial of children's access to quality education (Javaid et al., 2011). The Convention on the Rights of the Child (1989) was specially convened to cater for the rights of the children specifically in crises. The UN Convention on the Rights of the Child (CRC) has played a meaningful role in raising the emphasis on child protection issues in crisis (Javaid et al., 2011). 


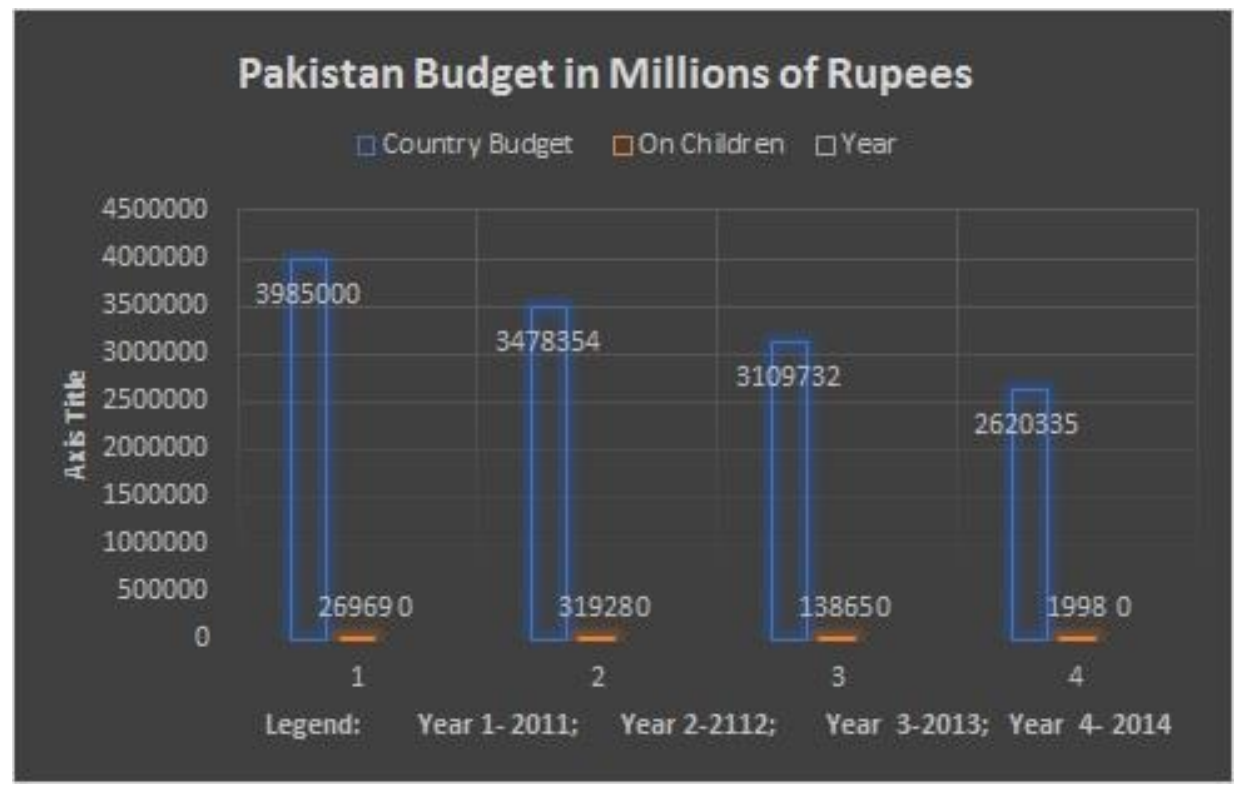

Figure 3

Source: Isjorgpk, 2018, retrieved 13 March 2018, from http://www.isj.org.pk/policy-research/

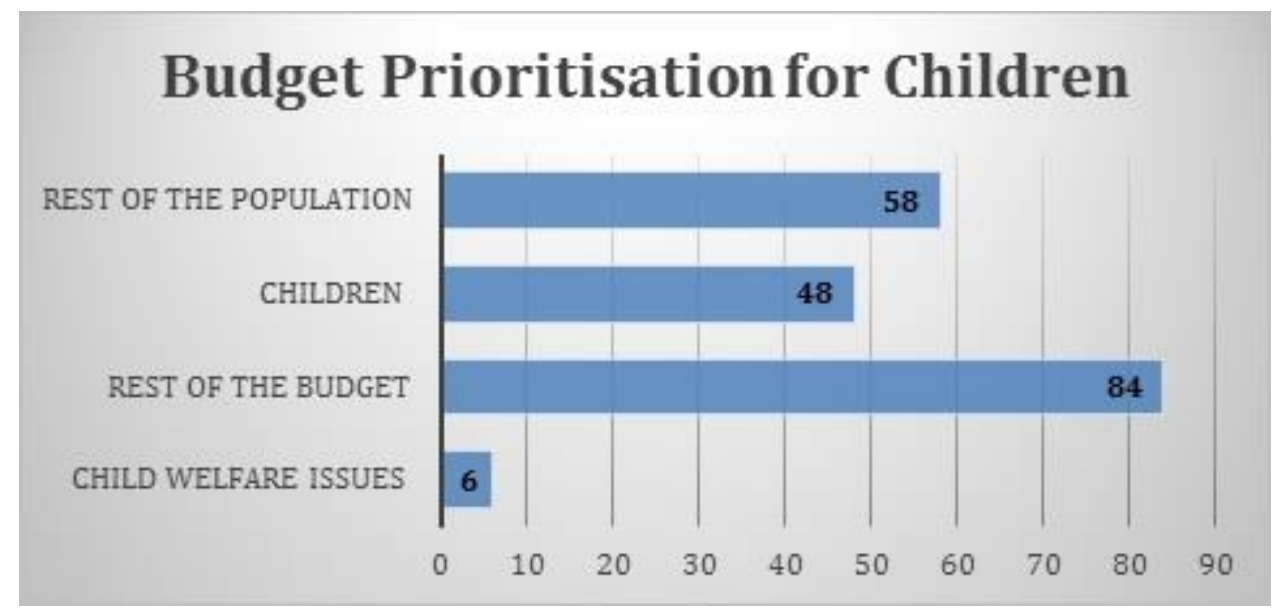

Figure 4

Source: Isjorgpk, 2018, retrieved 13 March 2018, from http://www.isj.org.pk/policy-research/

Yet, Pakistan is still, unfortunately, struggling with the implementation of the child protection system. According to Pakistan's Consolidated Third and Fourth Periodic Report to the UN Committee on the implementation of the Convention on the Rights of the Child, in child protection, the Pakistan government has made amendments in the Hadood Ordinance through the prevention of Anti-Women Practices (Criminal Law) Amendment-10-Act, 2006 as well as Punjab Destitute and Neglected Children Act, 2004, which was enacted by the government of the Punjab. Moreover, in 2007, an assessment of the child protection monitoring and data collection system was brought in (Government of Pakistan, 2016).
In each province, the Directorate of Social Welfare and Bait-ul-Mal is operating some institutions for child protection, such as 'Nigheban' Child Watch; (for the lost and run away children), 'Kashana' (an orphanage for girls) and Model Children's Home (an orphanage for boys), etc. However, there is no data about the services and conditions of these institutions (Government of the Punjab, 2016). The hopeful picture in the child protection system of Pakistan is partly served by the notfor-profit and private sector, which is working tirelessly to resolve the issues about safety and security of children. There are nongovernmental organisations both local and supported by foreign aid employ social activists and charity workers who work collaboratively 
at many levels to raise their support to the rights of the Pakistani children. These organisations are working in the sectors such as health, education, and social welfare. It is due to the effort of such organisations that an enormous net of bonded labour has come into the public eye, and there is legislation now in process to eradicate this menace. This first came to light when a kiln worker in a deteriorated physical and emotional health approached a local social activist. The kiln workers are used as bonded labour for a small amount of money, which then keeps massing interest for food and rest that these workers get. Hence, the debt never decreases, and the entire families must work as slaves. These families include children as young as newborns and are forced to live in the horrendous conditions. With some changes in policy, the Government has brought in legislation against bonded labour and the mistreatment of children and families.

As mentioned elsewhere in the paper, issues such as poverty, unemployment, illiteracy, natural calamities, lack of access to the health system for the poor, rampantly growing corrupt political and judicial system, and terrorism, exacerbate and compound the situation for issues linked to child protection. Take, for instance, children born in custodial institutions such as prisons. These children continue to be exposed to other convicts and grow amidst convicts while female prisoners languish without a conviction as a result of an overburdened judicial system. Organisations such as Amnesty International are working in collaboration with UNICEF to assist the formulation of an active policy so that the 'innocent' born in the prison system is appropriately looked after. An absence of proper juvenile detention centres is yet another aspect that accounts for manipulation and perpetuated crime against children as the juvenile offender is housed with adults in the prisons.

Thus, it is evident that there is not a single approach to resolve the issues of child protection system in Pakistan as it is a highly complex society. Some believe that Child protection systems overemphasise the response aspect of child protection and afford limited attention to prevention (Wessells, 2015). There are some suggestions in this respect. They are-first, it requires a mandatory top down approach of legislative framework, policies and capacities to support actions to be taken. Second, it requires a bottom up approach that involves community action, building community strengths that encourages community and government collaboration. Third, is the middle-out approach in which local authorities such as city councils promote child protection agendas within their regional centres of power (Wessells, 2015). It is believed that if the government and local authorities support community driven action, which will strengthen the child support system and increase protection for vulnerable children. Communities can play a vital role in protecting vulnerable children; this can include reconsidering social relations and cultural norms that may put children at risk, supporting victims of abuse, challenge offenders' behaviours, and by supporting families to provide basic needs for their children and by addressing the multidimensional poverty of the poor households (Jabeen, 2016; Wessells, 2015).

Need for convergence of legal, and social welfare stakeholders and reform to address the challenges that the child protection system cannot be underscored. While the nongovernmental organisations are the frontrunners in prevention and protection, however, they do not have adequate number of qualified social workers. Trained humanpower could provide therapeutic counseling, motivational interviewing, thus, enabling children and families to live through and negotiate with supports and better opportunities.

\section{Conclusion}

The key purpose of this article was to address the challenges faced in its child protection system by Pakistan. It is imperative to increase public awareness and use the platforms of advocacy deployed by the civil society in 
Pakistan to improve the situation of child protection in the country. With the implementation of significant political and legal reforms, the country will enhance the status of the efforts undertaken for the progress of child protection system. It is important that any legislation and policies put in place are not only in line with international expectations but also workable at the ground roots level. This will not only involve giving workers the resources they require but also clear guidelines on their responsibilities and the roles within the community. Currently, the evidence suggests that the present workers are unable to fulfil their role due to lack of clarity in guidelines and procedures. One of the broader issues that are blocking effective child protection in Pakistan is its cultural norms and beliefs. Therefore, it is imperative to include the community in solving this issue, as it requires the city to reflect on their values and beliefs and decide if they are in fact putting their children at risk.

\section{References}

Arif, G.M. (2004). Bonded Labour in Agriculture: a Rapid Assessment in Punjab and North West Frontier Province, Pakistan. Geneva:

International Labor office, retrieved 01 January 2018 from,

http://www.ilo.org/wcmsp5/groups/public/@e d_norm/@dec

laration/documents/publication/wcms_082027 .pdf

Azami, D. (2014, 15 December). How the Taliban groom child suicide bombers. BBC World Service, retrieved 15 December 2015 from, http://www.bbc.com/news/world-asia27250144

BBC (2011, 1 August). Pakistan floods: Children's stories, retrieved 17 November 2017 from, http://www.bbc.com/news/world-south-asia14346834

BBC (2010, 16 August). Millions of Pakistan children at risk of flood diseases, retrieved 20 December 2017 from, http://www.bbc.com/news/world-south-asia10984477
Bhattacharyya, R. (2015). Working childhoods: Youth, Agency and the Environment in India, Progress in Development Studies, 15(3), 292294, DOI: $10.1177 / 1464993415578570$

Bhattacharyya, R. (2017). Sociologies of India's missing children, Asian Social Work and Policy Review, 11(1), 90-101, DOI:10.1111/aswp.12116

Bhattacharyya, R. (2018). Living with Armed Forces Special Powers Act (AFSPA) as everyday Life, GeoJournal, 83(1), 31-48, DOI:

10.1007/s10708-016-9752-9

Bureau of International Labour Affairs. (2015). Child Labor and Forced Labor Reports, Pakistan. USA: United States Department of Labour, retrieved 20 December 2017 from, https://www.dol.gov/agencies/ilab/resources/r eports/child-labor/pakistan

Constitution of the Islamic Republic of Pakistan (1973), retrieved 30 November 2017 from, http://www.na.gov.pk/uploads/documents/13 33523681_951.pdf

Gazdar, H. (2007). Class, caste or race: veils over social oppression in Pakistan, Economic and Political Weekly, 86-88.

Global coalition to protect education from attack (2014). Education under attack-2014, retrieved 17 March 2017 from, http://protectingeducation.org/sites/default/fil es /documents/ eua_2014_full_0.pdf

Global slavery index 2016, Australia: The Walk

Free Foundation, retrieved 17 November 2017 from, http://assets.globalslaveryindex.org/downl oads/Global+Slavery+Index+2016.pdf

Government of the Punjab. (2016). Child protection \& Welfare Bureau, retrieved 20 November 2017 from, https://cpwb.punjab.gov.pk/background

Government of the Punjab. (2016). Social Welfare Department, retrieved 20 November 2017 from, https://swd.punjab.gov.pk/history

Government of Pakistan (2016). Pakistan's consolidated third and fourth periodic report to the UN Committee on the rights of the child on the implementation of the convention on the 
rights of the child, Islamabad: National Commission for Child Welfare and Development Ministry of Social Welfare and Special Education Government of Pakistan, retrieved 20 November 2017 from, http://202.83.164.28/ministries/mohr/images/ news-and-

events/pakistan_crc_c_pak_1_adv.pdf

Heiberg, T. (ed.) (2005). Listen and speak out against sexual abuse of girls and boys, Norway: Save the Children, retrieved 20 November 2017 from, http://resourcecentre.savethechildren.se/sites/ default/files/documents/2673.pdf

Hobbs, C. J., Hanks, H. G. I., \& Wynne, J. M. (1993). Physical abuse: child abuse and neglect, Edinburgh: Churchill Livingstone.

Hopkins, S. (2014, 3 December). Paying their debts back brick by brick: The Pakistani modern day slaves trapped in a lifetime of hardship. Daily Mail, retrieved 20 November 2017 from, http://www.dailymail.co.uk/news/article2858775/Paying-debts-brick-brick-Pakistanimodern-day-slaves-trapped-lifetimehardship.html

Human Appeal. (2016). Pakistan earthquake 10 Years On, retrieved 20 November 2017 from, https://humanappeal.org.uk/appeals/pakistanearthquake-10-years-on/

Human Rights Commission of Pakistan (2014). State of Human Rights in Pakistan, retrieved 20 November 2017 from, http://hrcpweb.org/hrcpweb/data/ar14c/52\%20Children\%20-\%202014.pdf

Isjorgpk (2018), retrieved 13 March 2018 from, http://www.isj.org.pk/policy-research/

International Labour Organizations (2011). UNICEF and ILO call for end to hazardous and exploitative child labour on World Day Against Child Labour; Press Release 11 June 2011. Islamabad: International Labour Organizations, retrieved 20 November 2017 from, http://www.ilo.org/islamabad/info/public/pr/ WCMS_1578 08/lang--en/index.htm

Jabeen, T. (2016). Child protection legislation in Pakistan: Bringing international child rights obligations and local values together, Pakistan Journal of Criminology, 8(3), 16-33

Javaid, Z., Arshad, M., \& Khalid, A. (2011). Child protection in disaster management in South Asia: A case study of Pakistan, South Asian Studies, 26(1), 191-202, retrieved 20 November 2017 from, http://search.proquest.com.ezproxy1.acu.edu. $\mathrm{au} /$ docview $/ 1315320057$ ?accountid $=8194$

Jibeen, T., \& Roberts, William. (2014). From home to shelter home: Victimization of young women in Pakistan, Canadian Journal of Behavioural Science / Revue Canadienne Des Sciences Du Comportement, 46(4), 475-484.

Khan, A., Sayeed, A., Shaikh, S., Jamal, A., \& Kamran, S. (2013). Child protection system mapping and assessment 2013- Punjab. Collective for Social Science Research, UNICEF: Islamabad, retrieved20 November 2017 from, http://www.researchcollective.org/Documents /EXECUTIVE_SUMMARY_Punjab.pdf

Kassim, A. (2011, 21 June). 9-year-old girl told to be suicide bomber, Pakistan police say, CNN, retrieved 20 November 2017 from, http://edition.cnn.com/2011/WORLD/asia pcf/06/21/pakistan.child.suicide.bomber/

Khoso, A., Kayani, K., Aziz, M., Abass,M.H., Wasif, \& Toru, Z. (2012). Federal and provincial budget analysis from a child rights perspective,

Pakistan: Save the Children, retrieved 20 November 2017 from,

http://resourcecentre.savethechildren.se/sites/ default/files/documents/budget_analysis_repo rt_crs_2011-12_5.pdf

Labour Watch Pakistan (2011). Bonded and forced labour in Pakistan, retrieved 20 November 2017 from, http://labourwatchpakistan.com/bonded-andforced-labour-in-pakistan/

Malekpour, M. (2004). Child abuse: A review of current research, Pakistan, Journal of Psychological Research, 19(1), 73-88, retrieved 20 November 2017 from, http://search.proquest.com.ezproxy1.acu.edu. au/docview/89070789? accountid=8194 
Massod, S. Muhammad. W., Amir, A. (2012). Multi-dimensional measurement of poverty in Pakistan, MPRA Paper No. 41532, Unimuenchende, retrieved 3 March 2018 from, https://mpra.ub.unimuenchen.de/41532/1/MPRA_paper_41532.p df

Mehnaz, A. (2011). State of children in Pakistan-confronting reality, The Journal of the Pakistan Medical Association, 61(6), 518-519, retrieved 20 November 2017 from, http://jpma.org.pk/PdfDownload/2810.pdf

Munir, A. B. B. (1993). Child protection: Principles and applications, Child Abuse Review, 2(2) 119-126.

Naveed, A., \& Ali, N. (2012). Clustered deprivation: District profile of poverty in Pakistan, Islamabad: Sustainable Development Policy Institute, retrieved 20 November 2017 from, https://sdpi.org/publications/files/Clustered\%2 0Deprivationdistrict\%20

profile\%20of\%20poverty\%20in\%20pakistan.pdf

Osment, L. (2014). Child labor: the effect on child, causes and remedies to the revolving menace, Sweden: University of Lund, retrieved 20 November 2017 from, http://lup.lub.lu.se/luur/download?func=downl oadFile \& recordOId $=4275652 \&$ fileOld $=4275654$

Pakistan: Child abuse can stunt normal growth: Expert. (2013). Right Vision News, retrieved 20 November 2017 from, http://search.proquest.com.ezproxy1.acu.edu. au/docview/ 1324994117?accountid=8194

Parton, N. (2011). Child protection and safeguarding in England: Changing and competing conceptions of risk and their implications for social work, British Journal of Social Work, 41(5), 854-875.

Pulla, V. (2014). Child protection system reform in the regional consultations of the south Asian nations, Malaysian Journal of Social Administration, 10, 23-34

Rehmatullah, S. (2002). Social welfare in Pakistan, Karachi: Oxford University press.
Royal College of Pediatric and Child Health (2016). Child protection, retrieved 20 November 2017 from, http://www.rcpch.ac.uk/improving-childhealth/child-protection/child-protection

Save the Children, Sweden (2010). Stepping up child protection: An assessment of child protection systems from all countries in South Asia, including Reflections from Central Asia, Kathmandu, Nepal: Save the Children Sweden.

Save the Children \& UNICEF. (2005). Disciplining the child practices \& impacts, NWFP: School \& Literacy Department.

Solotaroff, J.L. \& Pande R.P. (2014). Violence against women and girls: Lessons from South Asia, Washington, DC: World Bank Publications.

South Asia initiative to end violence against children (SAIEVAC) (2011).

Prohibition of corporal punishment of children in South Asia: A progress review, Nepal: Save the Children, Sweden. Retrieved 20 November 2017 from, http://resourcecentre.savethechildren.se/sites/ default/files/documents/5565.pdf

Suhail, L. (1990, 8 December). Pakistan certainly has a caste system, The New York Times, retrieved 20 November 2017 from, http://www.nytimes.com/1990/12/08/opinion /I-pakistan-certainly-has-a-caste-system224690.html

Tohid, O. (2011, 16 June). Pakistani teen tells of his recruitment, training as suicide bomber, retrieved 20 November 2017 from, http://www.csmonitor.com/World/Asia-SouthCentral/2011/0616/Pakistani-teen-tells-of-hisrecruitment-training-as-suicide-bomber

UNESCO (2014). School-related gender-based violence in the Asia-Pacific region, Bangkok, Thailand: UNESCO, retrieved 20 November 2017 from, http://unesdoc.unesco.org/images/0022/0022 67/226754E.pdf

UNICEF (2013). Annual report Pakistan. Islamabad, Pakistan, retrieved 20 November 2017 from, 
http://www.unicef.org/pakistan/FINAL_UNICEF _Annual_Report_2013_-_Version_11.1.pdf

UNICEF (2014). Improving children's lives, transforming the future -25 years of child rights in South Asia, retrieved from http://www.unicef.org/publications/files/Impr oving_Children_s_Lives__Transforming_the_Future_9_Sep_2014.pdf

UNICEF (2015). Afghanistan and Pakistan

Earthquake: children cut off from aid, retrieved 20 November 2017 from,

http://www.unicef.org.uk/Media-centre/Press-
releases/Afghanistan-and-Pakistan-EarthquakeChildren-cut-off-from-aid---Unicef/

Wessells, M. (2015). Bottom-up approaches to strengthening child protection systems: Placing children, families, and communities at the centre, Child abuse \& neglect, 43, 8-21, .DOI: org/10.1016/j.chiabu.2015.04.006

\section{Acknowledgements}

The authors are grateful to the anonymous referees and Dr Rituparna Bhattacharyya for their valuable suggestions, which helped us to improve this article. 